\title{
Protective effect of Antigonon leptopus (Hook et. Arn) in cadmium induced hepatotoxicity and nephrotoxicity in rats
}

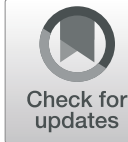

\author{
Madhuri Poosa and Swaroopa Rani Vanapatla*
}

\begin{abstract}
Background: Antigonon leptopus is a medicinal plant its leaves has not been reported for protective effects against cadmium induced hepatorenal toxicity. Cadmium (Cd) is a non-essential toxic metal used in industrial process, causes severe risk to human health with high levels. It is accumulated primarily in liver and kidney.

Methods: Male Wistar albino rats (200-250 g) were divided into 6 groups $(n=6)$ and had free access to diet and water. Cadmium chloride (5 mg/kg b.w/day) was administered orally for 21 days and methanolic extract of Antigonon leptopus (ALME) was administered to groups of cadmium treated rats at daily doses of 100, 200 and 400 mg/kg b.w;p.o. for 21 days. At the end, liver and kidney markers along with antioxidant parameters are evaluated.

Results: The results indicated that, administration of cadmium significantly $(p<0.05)$ increased the levels liver enzymes in serum and bilirubin levels, decreases in total proteins and albumin; in addition to the levels of uric acid, urea and creatinine were increased in the serum. Glutathione (GSH) levels and the enzyme catalase activities were significantly $(p<0.05)$ decreased while lipid peroxidation was increased in hepatic and renal tissues of cadmium treated rats. The pre-administration of ALME at all the three test doses, alleviated hepatorenal toxicity in cadmium treated rats, used Silymarin $(100 \mathrm{mg} / \mathrm{kg})$ as standard. Moreover, ALME treatment was able to reverse the histopathological changes in liver and kidney tissues, and increased the red blood cells, hemoglobin content and decreased prothrombin time and white blood cells.

Conclusion: Among all the three test doses, ALME at $200 \mathrm{mg} / \mathrm{kg}$ have shown significant antioxidant effect and also exerts beneficial effect against cadmium induced hepatorenal toxicity.
\end{abstract}

Keywords: Cadmium, Antigonon leptopus, Hepatoprotective activity, Nephroprotective activity, Antioxidant activity

\section{Introduction}

Cadmium $(\mathrm{Cd})$ is a common toxic heavy metal in the environment. $\mathrm{Cd}$ is a highly accumulative toxicant with very long biological half-life of over 20 years. Cadmium is not biodegradable and its level in the environment is increasing due to industrial activities, and human exposure to $\mathrm{Cd}$ is inevitable [1,2]. The blood cadmium level in human adults is $0.38 \mu \mathrm{g} / \mathrm{L}$ and the minimal risk level is $0.5 \mu \mathrm{g} / \mathrm{kg} /$ day. Cadmium is virtually absent at birth in

\footnotetext{
*Correspondence: swarooparanivanapatla@gmail.com

Department of Pharmacognosy and Phytochemistry, University College of Pharmaceutical Sciences, Kakatiya University, Warangal, Telangana 506009, India
}

mammals but accumulates with time especially in the sults from smoking, Cd-contaminated sea foods and water [4]. Epidemiological and experimental evidence suggested that acute exposure induces oxidative stress through the inhibfrom an imbalance in the production of reactive oxygen species (ROS) and the ability of the cell to scavenge them. The associated toxic effects of cadmium attributed to suppression of free radical scavenging function and 
the enhancement of reactive oxygen species. ROS that react with nucleic acids, proteins and lipids results in cell and tissue damage [5].

In recent times, the use of traditional medicine is increasingly gaining popularity in both developed and developing countries. The therapeutic values of many plants have been identified and exploited for the management of many disease conditions [1].

Antigonon leptopus Hook et. Arn (family- Polygonacae) is native to Mexico and commonly found in tropical Asia, Africa, Caribbean and in America. In India, it is most common in the upper Ganges plains and Himalayan regions. Traditionally the leaves are used to reduce swelling and to treat diabetes, hypertension and menstrual pains. A tea prepared from the leaves used foe diabetes. The vine is used to treat cough and throat constrictions. In Chinese traditional medicine, it is used for the treatment of nephritis, hepatitis and colitis [6]. To the best of our knowledge, there is no report on the protective effects of Antigonon leptopus leaves against $\mathrm{Cd}$ induced hepatotoxicity and nephrotoxicity in rats. Therefore, this study evaluated the hepatorenal protective potential of the methanolic extract of Antigonon leptopus on Cd-intoxicated rats.

\section{Materials and methods}

\section{Drugs and chemicals}

Silymarin-Sigma Aldrich, Spruce street, St. Louis, China; The analytical kits for determination of AST, ALP, ALT, TB, DB, TP, ALB, Urea, Uric acid, Creatinine were purchased from - Merck specialities private limited, Mumbai, India; TCA, TBA and Cadmium were purchased from Himedia, Mumbai, India; $\mathrm{H}_{2} \mathrm{O}_{2}$, NBT - Sigma, Germany; All other chemicals and solvents used were of analytical grade.

\section{Animals}

Male wistar albino rats weighing 200-250 g were purchased from Mahaveer agencies, Hyderabad, India with a prior permission from our institutional animal ethical committee (IAEC 32 UCPSC 2018) and used for the studies. The animals were kept in wire bottomed cages in a room under standard condition of illumination with 12-h light-dark cycle at $25 \pm 5^{\circ} \mathrm{C}$ for 1 week until the beginning of experiment. They were provided with tap water and balanced diet ad libitum.

\section{Plant material}

One kilogram of the leaves was collected in and around Kakatiya University campus, Warangal, Telangana in the months of July and August. The plant material was aunthenticated by Dr. V.S.Raju (Taxonomist), Department of Botany, Kakatiya University, Warangal. The voucher specimen of this plant material is being maintained in the herbarium of Department of Pharmacognosy and phytochemistry, U.C.P.Sc, Kakatiya University, Warangal for future reference.

\section{Preparation of extract}

The freshly collected leaves of Antigonon leptopus were shade dried and powdered. The powdered material was extracted with methanol by maceration for 7 days in round bottom flask at room temperature. Filtrate was concentrated under reduced pressure (Rotavapour ${ }^{\circ}$ Switzerland) to obtain a semi solid mass of ALME. The methanolic extract was tested for carbohydrates, amino acids, proteins, fixed oils, alkaloids, polyphenols, glycosides, flavonoids, tannins, saponins, volatile oils, steroids.

\section{Acute toxicity study}

Acute toxicity study was performed according to test dose guideline 423 of Organisation for Economic and Cultural Development (OECD). All groups of animals were recorded within the $24 \mathrm{~h}$ duration for percentage mortality and observed for further 14 days for any sign for delayed toxicity.

\section{Experimental design}

To study the protective effects of ALME in cadmium mediated hepatorenal toxicity, adult male Wistar rats were randomly allocated to six groups of six rats per group $(n=6)$. The animals were pre-treated orally with the test material/standard drug suspended in $2 \%$ Gum acacia for 21 days along with cadmium $(5 \mathrm{mg} / \mathrm{kg}$ b.w/ day) in their drinking water.

Group I (Control): Received 2\% Gum acacia in water by oral administration route everyday for 21 days.

Group II (Toxic): Received 2\% Gum acacia followed by cadmium for 21 days.

Group III (Standard): Treated with Silymarin (100 mg/ $\mathrm{kg}$ ) b.w;p.o. followed by cadmium for 21 days.

Group IV: Treated with ALME $(100 \mathrm{mg} / \mathrm{kg})$ b.w;p.o. followed by cadmium for 21 days.

Group V: Treated with ALME $(200 \mathrm{mg} / \mathrm{kg})$ b.w;p.o. followed by cadmium for 21 days.

Group VI: Treated with ALME $(400 \mathrm{mg} / \mathrm{kg})$ b.w;p.o. followed by cadmium for 21 days.

After 21 days of the treatment, blood samples were collected by retro orbital puncture from overnight fasted rats under ether anesthesia. The serum obtained after centrifugation (3000 rpm for $10 \mathrm{~min}$ ) was used for various serum biochemical parameters such as Alanine aminotransferase (ALT), Aspartate aminotransferase (AST), Alkaline phosphatase (ALP), Total bilirubin (TB), Direct bilirubib (DB), Total proteins (TP), Albumin (ALB), Urea, Creatinine and Uric acid. For determination of RBCs (Red blood cells), WBCs (White blood cells) and hemoglobin content $(\mathrm{Hb})$, blood samples were collected 
in test tubes contained disodium salt of ethylene diamine tetra acetic acid (EDTA). Parts of the liver and kidney were excised, weighed and homogenized immediately to give $50 \%(\mathrm{w} / \mathrm{v})$ homogenate in ice-cold medium containing $1.15 \% \mathrm{KCL}, \mathrm{pH} 7.4$. The homogenate was centrifuged at $3000 \mathrm{rpm}$ for $10 \mathrm{~min}$ at $4{ }^{\circ} \mathrm{C}$. The tissue homogenate was used to estimate Glutathione (GSH), malonaldehyde (MDA) and catalase (CAT) levels. Their percentage protection was calculated by using the formula.

$$
\text { Percentage protection }=\left\{1-\frac{(T-V)}{(C-V)}\right\} \times 100
$$

Where " $\mathrm{T}$ " is the mean value of test group (extract/ standard), "C" is the mean value of toxic group (Cadmium) alone and "V" is the mean value of control group.

\section{Histological studies}

The liver and kidney tissue samples were washed in saline and fixed in 10\% phosphate buffered formalin, embedded in paraffin, sectioned at $5 \mu \mathrm{m}$, and stained with hematoxylin and eosin for light microscopic observations.

\section{Antioxidant studies}

Liver and kidney homogenates were used to determine MDA by reaction of thiobarbituric acid [7], Similarly GSH [8] and CAT [9] were assayed by using different methods.

\section{Stastical analysis}

Stastical analysis was carried out by one way of variance (ANOVA) followed by Durnett ' $\mathrm{t}$ ' test, using graph pad prism 6.0, $P$ values $<0.05$ were considered as significant. The results were expressed as mean $\pm \mathrm{SD}, n=6$.

\section{Results}

\section{Phytochemical screening}

The preliminary phytochemical screening of methanolic extract of Antigonon leptopus leaves exhibited the presence of polyphenols, flavonoids, tannins, glycosides, carbohydrates, steroids and saponins.

\section{Acute toxicity study}

Acute oral toxicity studies revealed the methanolic extract of Antigonon leptopus did not cause any adverse effects and mortality up to a dose level of $2000 \mathrm{mg} / \mathrm{kg}$ in rats. Hence, three doses 100, 200 and $400 \mathrm{mg} / \mathrm{kg}$ b.w of methanolic extracts were selected for conducting hepatoprotective, nephroprotective and antioxidant studies.

\section{Effect on liver biochemical parameters}

Table 1 showed the serum hepatic marker enzyme levels and bilirubin of all experimental rats. Oral administration of cadmium caused a significant liver injury manifested by significant elevation in activities of AST, ALP, ALT, TB, DB and decrease in serum total protein and albumin. ALME at 100, 200 and $400 \mathrm{mg} / \mathrm{kg}$ b.w showed a significant decrease $(p<0.05)$ in serum liver enzymes (AST, ALT, ALP) bilirubin and increase in serum total protein and albumin. Among all the three doses, significant percentage protection shown by ALME at $200 \mathrm{mg} /$ $\mathrm{kg}$ b.w was relatively better than ALME at 100 and 400 $\mathrm{mg} / \mathrm{kg}$.

\section{Effect on kidney biochemical parameters}

Exposure to $\mathrm{Cd}$ caused a significant increase in serum uric acid, urea and creatinine levels when compared to the control values which was shown in Table 2. Treatment with ALME at three doses 100, 200 and $400 \mathrm{mg} / \mathrm{kg}$ significantly reduced the elevated levels of serum Uric acid, Urea and Creatinine. Among all the test doses, percentage protection shown by ALME at $200 \mathrm{mg} / \mathrm{kg}$ b.wt was relatively better than ALME at 100 and $400 \mathrm{mg} / \mathrm{kg}$, it was well comparable to that of standard drug Silymarin at $100 \mathrm{mg} / \mathrm{kg}$.

Table 1 Hepatoprotective effect of ALME on different biochemical parameters in cadmium induced liver damage in rats

\begin{tabular}{llllllll}
\hline Experimental Groups & AST $(\mathrm{U} / \mathrm{L})$ & ALT $(\mathrm{U} / \mathrm{L})$ & $\mathrm{ALP}(\mathrm{U} / \mathrm{L})$ & $\mathrm{TB}(\mathrm{mg} / \mathrm{dl})$ & $\mathrm{DB}(\mathrm{mg} / \mathrm{dl})$ & $\mathrm{TP}(\mathrm{g} / \mathrm{dl})$ & $\mathrm{ALB}(\mathrm{g} / \mathrm{dl})$ \\
\hline Normal & $51.81 \pm 3.56$ & $52.7 \pm 1.9$ & $119.5 \pm 3.23$ & $0.21 \pm 0.04$ & $0.07 \pm 0.04$ & $9.94 \pm 0.35$ & $5.89 \pm 0.53$ \\
Toxic $(\mathrm{Cd})(5 \mathrm{mg} / \mathrm{kg})$ & $83.62 \pm 2.38$ & $135.78 \pm 4.3$ & $168.3 \pm 7.51$ & $1.03 \pm 0.14$ & $1.04 \pm 0.07$ & $4.37 \pm 0.39$ & $3.07 \pm 0.25$ \\
Silymarin $(100 \mathrm{mg} / \mathrm{kg})$ & $55.31 \pm 2.53^{* *}$ & $63.15 \pm 4.5^{* *}$ & $127.3 \pm 3.51^{* *}$ & $0.30 \pm 0.08^{* *}$ & $0.27 \pm 0.03^{* *}$ & $9.36 \pm 0.49^{* *}$ & $4.94 \pm 0.52^{* *}$ \\
& $(88.99 \%)$ & $(87.42 \%)$ & $(84.01 \%)$ & $(89.02 \%)$ & $(79.38 \%)$ & $(89.58 \%)$ & $(66.31 \%)$ \\
& $70.15 \pm 4.12^{*}$ & $80.03 \pm 6.11^{*}$ & $145.5 \pm 8.4^{*}$ & $0.66 \pm 0.05^{*}$ & $0.55 \pm 0.03^{*}$ & $7.97 \pm 0.4^{*}$ & $4.48 \pm 0.23^{*}$ \\
ALME $(100 \mathrm{mg} / \mathrm{kg})$ & $(42.34 \%)$ & $(67.10 \%)$ & $(46.72 \%)$ & $(45.12 \%)$ & $(50.51 \%)$ & $(64.63 \%)$ & $(50.70 \%)$ \\
& $62.79 \pm 5.21^{* *}$ & $65.58 \pm 7.7^{* *}$ & $132.4 \pm 4.14^{* *}$ & $0.48 \pm 0.09^{* *}$ & $0.39 \pm 0.03^{* *}$ & $9.07 \pm 0.58^{* *}$ & $4.8 \pm 0.48^{* *}$ \\
ALME (200 mg/kg) & $(65.48 \%)$ & $(84.49 \%)$ & $(73.56 \%)$ & $(67.07 \%)$ & $(67.01 \%)$ & $(84.38 \%)$ & $(61.34 \%)$ \\
& $68.53 \pm 3.18^{*}$ & $74.13 \pm 1.68^{* *}$ & $139.11 \pm 5.9^{* *}$ & $0.53 \pm 0.08^{* *}$ & $0.42 \pm 0.04^{* *}$ & $8.39 \pm 0.36^{* *}$ & $4.66 \pm 0.23^{*}$ \\
ALME (400 mg/kg) & $(47.43 \%)$ & $(74.20 \%)$ & $(59.83 \%)$ & $(60.97 \%)$ & $(63.91 \%)$ & $(72.17 \%)$ & $(56.38 \%)$ \\
\hline
\end{tabular}

Values are expressed as mean $\pm \mathrm{SD}, n=6$. ${ }^{* *} P<0.01,{ }^{*} P<0.05$. $P$ value- Control versus other groups. 
Table 2 Effect of ALME on cadmium induced changes in different serum kidney biochemical parameters

\begin{tabular}{llll}
\hline Experimental groups & Urea $(\mathrm{mg} / \mathrm{dL})$ & Creatinine $(\mathrm{mg} / \mathrm{dL})$ & Uric acid $(\mathrm{mg} / \mathrm{dL})$ \\
\hline Normal & $5.73 \pm 0.26$ & $0.59 \pm 0.09$ & $2.73 \pm 0.12$ \\
Toxic $(\mathrm{Cd})$ & $13.57 \pm 0.92$ & $1.23 \pm 0.08$ & $5.13 \pm 0.32$ \\
$(5 \mathrm{mg} / \mathrm{kg})$ & & & $3.13 \pm 0.15^{* *}$ \\
Silymarin & $6.35 \pm 0.27^{* *}$ & $0.98 \pm 0.13^{* *}$ & $(83.33 \%)$ \\
$(100 \mathrm{mg} / \mathrm{kg})$ & $(92.09 \%)$ & $(39.06 \%)$ & $4.31 \pm 0.13^{*}$ \\
ALME & $9.03 \pm 0.42^{*}$ & $1.11 \pm 0.03^{*}$ & $(34.16 \%)$ \\
$(100 \mathrm{mg} / \mathrm{kg})$ & $(57.90 \%)$ & $(18.75 \%)$ & $3.25 \pm 0.09^{* *}$ \\
ALME & $7.12 \pm 0.38^{* *}$ & $1.01 \pm 0.11^{* *}$ & $(78.33 \%)$ \\
$(200 \mathrm{mg} / \mathrm{kg})$ & $(82.27 \%)$ & $(34.37 \%)$ & $4.01 \pm 0.21^{*}$ \\
ALME & $8.08 \pm 0.43^{* *}$ & $1.09 \pm 0.06^{*}$ & $(46.66 \%)$ \\
$(400 \mathrm{mg} / \mathrm{kg})$ & $(70.02 \%)$ & $(21.87 \%)$ &
\end{tabular}

. Values are expressed as mean $\pm \mathrm{SD}, n=6$. ${ }^{*} P<0.01,{ }^{*} P<0.05$. $P$ value- Control versus other groups.

\section{Effect on oxidative stress parameters}

The effect of ALME on oxidative parameters has been represented in Tables 3 and 4. Oral administration of cadmium caused increased levels of MDA and decreased levels of GSH, CAT in hepatic and renal tissues, which are reversed upon administration of ALME at three test doses $(100,200$ and $400 \mathrm{mg} / \mathrm{kg})$, the results indicate that ALME at $200 \mathrm{mg} / \mathrm{kg}$. b.w afforded better protection as compared to ALME at 100 and $400 \mathrm{mg} / \mathrm{kg}$.

\section{Effect on prothrombin time}

Table 5 represents prothrombin time in rats of control group was found to be $16.7 \pm 3.5 \mathrm{~s}$ whereas treatment of animals with cadmium significantly prolonged the prothrombin time to $79.8 \pm 4.3 \mathrm{~s}$. Treatment of animals with ALME $(200 \mathrm{mg} / \mathrm{kg})$ and silymarin $(100 \mathrm{mg} / \mathrm{kg})$ significantly shortened the prothrombin time to $45.2 \pm 4.1$ and $37.2 \pm 4.5 \mathrm{~s}$ respectively in cadmium intoxicated rats.

\section{Hematological results}

Cadmium treated group showed a significant decrease in $\mathrm{RBCs}$ and $\mathrm{Hb}$ when compared with the control group,

Table 3 Effect of ALME on different antioxidant parameters in the liver tissue

\begin{tabular}{llll}
\hline Experimental groups & GSH $(\mathrm{mM} / \mathrm{mg})$ & $\mathrm{MDA}(\mathrm{mM} / \mathrm{mg})$ & CAT $(\mathrm{U} / \mathrm{mg})$ \\
\hline Normal & $7.12 \pm 0.72$ & $2.67 \pm 0.06$ & $11.07 \pm 0.2$ \\
Toxic $(\mathrm{Cd})$ & $3.06 \pm 0.21$ & $4.88 \pm 0.08$ & $4.06 \pm 0.09$ \\
$(5 \mathrm{mg} / \mathrm{kg})$ & & & \\
Silymarin & $5.92 \pm 0.39^{* *}$ & $3.01 \pm 0.05^{* *}$ & $9.79 \pm 0.3^{* *}$ \\
$(100 \mathrm{mg} / \mathrm{kg})$ & $(83.74 \%)$ & $(84.61 \%)$ & $(81.74 \%)$ \\
ALME & $4.34 \pm 0.35^{*}$ & $3.92 \pm 0.33^{*}$ & $7.92 \pm 0.43^{*}$ \\
$(100 \mathrm{mg} / \mathrm{kg})$ & $(31.52 \%)$ & $(43.43 \%)$ & $(55.06 \%)$ \\
ALME & $6.03 \pm 0.32^{* *}$ & $3.34 \pm 0.25^{* *}$ & $8.73 \pm 0.27^{* *}$ \\
$(200 \mathrm{mg} / \mathrm{kg})$ & $(73.15 \%)$ & $(69.68 \%)$ & $(66.61 \%)$ \\
ALME & $4.89 \pm 0.58^{*}$ & $3.49 \pm 0.38^{*}$ & $8.39 \pm 0.2^{*}$ \\
$(400 \mathrm{mg} / \mathrm{kg})$ & $(45.07 \%)$ & $(62.89 \%)$ & $(61.76 \%)$ \\
\hline
\end{tabular}

Values are expressed as mean $\pm \mathrm{SD}, n=6$. ${ }^{*} P<0.01,{ }^{*} P<0.05$. $P$ value- Control versus other groups. while WBCs increased in comparison with control rats, results shown in Table 6. In ALME treated groups, there was a significant increase in RBCs and $\mathrm{Hb}$ count when compared with $\mathrm{Cd}$ treated rats.

\section{Histopathological changes}

Figure 1 represents the histological findings of liver sections of cadmium intoxicated rats revealed remarkable changes in the normal liver architecture of rats showing focal necrosis, vacuolated cytoplasm, centrilobular necrosis, sinusoidal dilatation, hepatocytic vacuolation and inflammatory cell infiltration of hepatocytes.

All the three test doses of methanolic extract of A.Leptopus $(100,200$ and $400 \mathrm{mg} / \mathrm{kg}$ ), showed significant recovery from the cadmium induced hepatic damage with little dilatation of sinusoidal space, lesser necrotic zones. Among the three test doses, ALME at $200 \mathrm{mg} / \mathrm{kg}$ was well comparable to that of the reference drug, Silymarin (100 mg/kg).

Figure 2 showed histopathological examination of the kidney sections of cadmium intoxicated rats revealed remarkable changes in the normal kidney architecture of rats showing congested shrunk and completely

Table 4 Effect of ALME on different antioxidant parameters in the kidney tissue

\begin{tabular}{llll}
\hline Experimental groups & GSH $(\mathrm{mM} / \mathrm{mg})$ & MDA $(\mathrm{mM} / \mathrm{mg})$ & CAT $(\mathrm{U} / \mathrm{mg})$ \\
\hline Normal & $7.34 \pm 0.14$ & $1.44 \pm 0.04$ & $10.38 \pm 0.28$ \\
Toxic $(\mathrm{Cd} 5 \mathrm{mg} / \mathrm{kg})$ & $3.31 \pm 0.31$ & $3.53 \pm 0.08$ & $3.73 \pm 0.07$ \\
Silymarin $(100 \mathrm{mg} / \mathrm{kg})$ & $6.87 \pm 0.15^{* *}$ & $1.92 \pm 0.05^{* *}$ & $8.78 \pm 0.22^{* *}$ \\
& $(88.33 \%)$ & $(77.03 \%)$ & $(75.93 \%)$ \\
ALME & $4.91 \pm 0.36^{*}$ & $2.79 \pm 0.22^{*}$ & $7.65 \pm 0.42^{*}$ \\
$(100 \mathrm{mg} / \mathrm{kg})$ & $(39.70 \%)$ & $(35.40 \%)$ & $(58.94 \%)$ \\
ALME & $6.07 \pm 0.81^{* *}$ & $2.23 \pm 0.16^{* *}$ & $8.51 \pm 0.38^{* *}$ \\
$(200 \mathrm{mg} / \mathrm{kg})$ & $(68.48 \%)$ & $(62.20 \%)$ & $(71.87 \%)$ \\
ALME & $5.12 \pm 0.24^{*}$ & $2.39 \pm 0.32^{*}$ & $8.29 \pm 0.56^{*}$ \\
(400 $\mathrm{mg} / \mathrm{kg})$ & $(44.91 \%)$ & $(54.54 \%)$ & $(68.57 \%)$ \\
\hline Values are expressed as mean $\pm \mathrm{SD}, n=6 .{ }^{* *} P<0.01,{ }^{*} P<0.05 . P$ value- Control
\end{tabular}
versus other groups. 
Table 5 Effect of ALME on Prothrombin time (seconds) in cadmium intoxicated rats

\begin{tabular}{ll}
\hline $\begin{array}{l}\text { Experimental } \\
\text { Groups }\end{array}$ & $\begin{array}{l}\text { Prothrombintime } \\
\text { in seconds }\end{array}$ \\
\hline Normal & $16.7 \pm 3.5$ \\
Toxic $(\mathrm{Cd})$ & $79.8 \pm 4.3$ \\
$(5 \mathrm{mg} / \mathrm{kg})$ & \\
Silymarin & $37.2 \pm 4.5^{* *}$ \\
$(100 \mathrm{mg} / \mathrm{kg})$ & $(67.35 \%)$ \\
ALME & $59.3 \pm 5.1^{*}$ \\
$(100 \mathrm{mg} / \mathrm{kg})$ & $(32.48 \%)$ \\
ALME & $45.2 \pm 4.1^{* *}$ \\
$(200 \mathrm{mg} / \mathrm{kg})$ & $(54.83 \%)$ \\
ALME & $50.2 \pm 5.4^{*}$ \\
$(400 \mathrm{mg} / \mathrm{kg})$ & $(46.90 \%)$ \\
\hline
\end{tabular}

Values are expressed as mean $\pm \mathrm{SD}, n=6 .{ }^{* *} P<0.01,{ }^{*} P<0.05$. $P$ value- Control versus other groups.

degenerated glomeruli, debris in the lumen of some renal tubules and degeneration of renal tubules.

Treatment with all the three test doses $(100,200$ and $400 \mathrm{mg} / \mathrm{kg}$ ) showed a significant recovery from the cadmium induced renal damage with normal renal corpuscle and renal tubule more or less like normal structure. Among the three doses, ALME at $200 \mathrm{mg} / \mathrm{kg}$ was well comparable to that of the reference drug, Silymarin $(100 \mathrm{mg} / \mathrm{kg})$.

\section{Discussion}

In this study, it has been observed that acute cadmium intoxication caused hepatic and renal oxidative damages. Experimental results suggest that ALME at $200 \mathrm{mg} / \mathrm{kg}$ could prevent the $\mathrm{Cd}$-induced hepatic and renal oxidative damage in rats. The administration of $\mathrm{Cd}$ exerts possible hepatotoxicity as verified by the increase in serum AST, ALT, ALP levels and TB, DB levels with a concomitant decrease in albumin and total protein content as a result of hepatocellular necrosis, which causes alteration in the permeability of the cell membrane. High levels of serum AST and ALT are the crucial parameters to detect liver damage [10]. Cd causes structural and functional damage to the cell membrane and increased membrane permeability leading to the leakage of hepatic enzymes into the blood [11]. Serum ALP levels are also related to the status and function of hepatic cells. Increase in serum ALP is due to increased synthesis in the presence of increasing biliary pressure [12]. Elevated levels of ALP, AST and ALT enzymes in cadmium treated rats are significantly reduced by the treatment with ALME at all 3 test doses (100, 200 and 400 $\mathrm{mg} / \mathrm{kg} \mathrm{b.w)} \mathrm{and} \mathrm{also} \mathrm{stabilizes} \mathrm{the} \mathrm{hepatic} \mathrm{cellular} \mathrm{mem-}$ brane, protect the hepatocytes against toxic effects of cadmium.

The serum level of bilirubin (total and direct) has also been found to be increased in cadmium-intoxicated animals; increase in serum bilirubin is a clear marker of hepatic dysfunction [13, 14]. Moreover, cadmium exerts heme catabolism which ultimately leads to increased bilirubin levels in blood serum. ALME at 100, 200 and $400 \mathrm{mg} / \mathrm{kg}$ b.w. showed a significant decrease in serum bilirubin levels suggesting the possibility of the extract ability to repair the damage of the hepatocytes caused by cadmium in rats.

Albumin and total protein are synthetic functional markers, which are used to indicate the liver function. The decreased levels of albumin and TP in serum are due to decrease in synthetic capacity of the liver [15]. The hypoproteinemia and hypoalbuminemia in the present work could be attributed to liver damage and proteinuria as a renal dysfunction in laboratory animals which are common in cadmium toxicity [16]. Treatment with ALME showed increase in serum albumin and total protein levels with varying degree of significance. This may be due to hepataprotective effect of ALME on synthetic capacity of liver.

The kidney is generally recognized as the most critical organ affected by acute and chronic exposure to cadmium. Renal dysfunction in laboratory animals is commonly reported in cadmium toxicity. Cadmium reaches

Table 6 Effect of ALME on RBC, WBC and Hb content

\begin{tabular}{llll}
\hline $\begin{array}{l}\text { Experimental } \\
\text { Groups }\end{array}$ & RBCs $\left(10^{6} / \mu \mathrm{L}\right)$ & WBCs $\left(10^{3} / \mu \mathrm{L}\right)$ & $\mathrm{Hb}(\mathrm{g} / \mathrm{dL})$ \\
\hline Normal & $6.78 \pm 0.68$ & $10.56 \pm 0.42$ & $12.34 \pm 0.34$ \\
$\begin{array}{l}\text { Toxic }(\mathrm{Cd}) \\
(5 \mathrm{mg} / \mathrm{kg})\end{array}$ & $4.39 \pm 0.26$ & $11.98 \pm 0.73$ & $9.32 \pm 0.21$ \\
Silymarin $(100 \mathrm{mg} / \mathrm{kg})$ & $6.02 \pm 0.91^{* *}(68.20 \%)$ & $11.58 \pm 0.83^{* *}(85.55 \%)$ & $12.89 \pm 0.53^{* *}(81.78 \%)$ \\
ALME & $5.26 \pm 0.54^{*}(36.40 \%)$ & $13.12 \pm 0.55^{*}(63.73 \%)$ & $10.13 \pm 0.12^{* *}(26.82 \%)$ \\
$(100 \mathrm{mg} / \mathrm{kg})$ & $5.89 \pm 0.74^{* *}(62.76 \%)$ & $12.69 \pm 0.47^{* *}(69.83 \%)$ & $11.41 \pm 0.68^{* *}(69.20 \%)$ \\
ALME & & & $12.85 \pm 0.37^{* *}(67.56 \%)$ \\
$(200 \mathrm{mg} / \mathrm{kg})$ & $5.18 \pm 0.85^{* *}(33.05 \%)$ & $10.38 \pm 0.71^{* *}(35.09 \%)$ \\
ALME & & &
\end{tabular}

Values are expressed as mean $\pm \mathrm{SD}, n=6 .{ }^{* *} P<0.01,{ }^{*} P<0.05 . P$ value-Control versus other groups. 


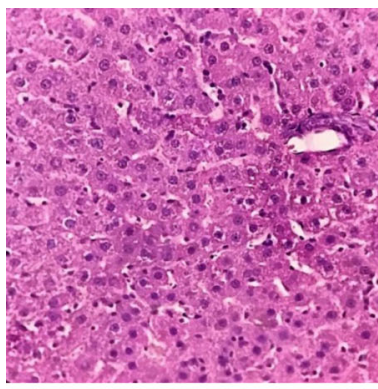

(A) Control group

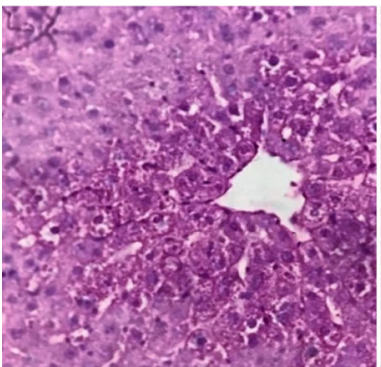

(D) ALME $100 \mathrm{mg} / \mathrm{kg}$

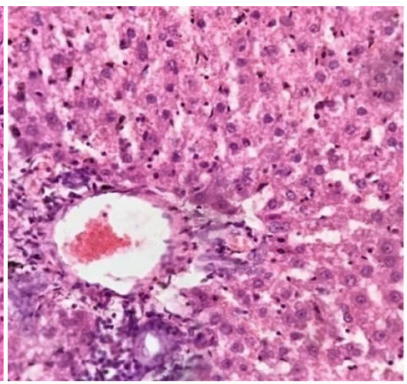

(B) Toxic group

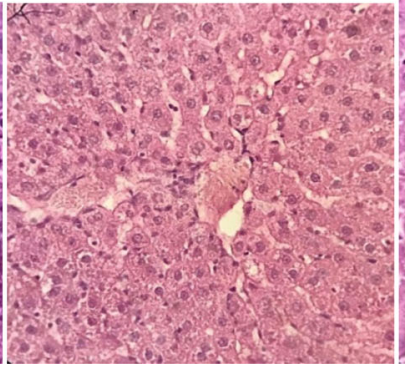

(E) ALME 200mg/kg

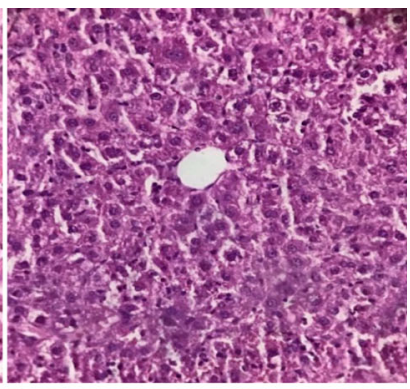

(C)Silymarin $100 \mathrm{mg} / \mathrm{kg}$

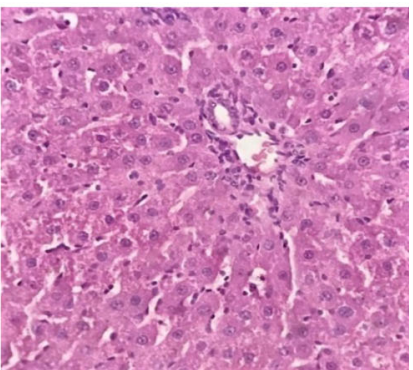

(F) ALME 400mg/kg

Fig. 1 Histopathological changes in hepatic tissue of rats. Done by Digital Motic Microscope Magnification 100X. a A control liver with normal architecture. b Rats treated with cadmium alone, with focal necrosis, vacuolated cytoplasm, centrilobular necrosis, sinusoidal dilatations,

hepatocytic vacuolation and inflammatory cell infiltration of hepatocytes. c And e Rats treated with Standard and ALME $200 \mathrm{mg} / \mathrm{kg}$, along with cadmium exhibited normal liver architecture. $\mathbf{d}$ Rats treated with ALME $100 \mathrm{mg} / \mathrm{kg}$ and cadmium exhibited mild focal necrosis and minimal damage. $\mathbf{f}$ Rats treated with ALME $400 \mathrm{mg} / \mathrm{kg}$ and cadmium maintained the hepatic architecture, more or less like normal

the kidney in the form of cadmium-metallothionein that is filtered in the glomerulus, and subsequently reabsorbed in the proximal tubules. It is then remains in the tubule cells and results in nephrotoxicity [17].

Cadmium treated animals showed increased levels of urea, uric acid and creatinine and decreased levels of serum albumin and total protein. Urea, creatinine and uric acid are the waste products of protein metabolism. They are formed in the liver and conveyed in blood to the kidneys for excretion. The disorders associated with impairment in renal function cause increase in levels of uric acid, creatinine and urea. Since cadmium impaired the glomerular filtration, the urea, creatinine and uric acid are accumulated in the blood. Decrease in serum total protein and albumin indicates loss of these components in the urine as a result of cadmium induced glomerular and tubular injury. Treatment with ALME significantly prevented the increase in serum uric acid, urea, creatinine and decrease in serum albumin and total protein. This may be due to improvement in the cadmium nephrotoxicity and degenerative alterations in renal corpuscles and renal tubules.

Prothrombin time (PT) is a blood test that measures how long it takes blood to clot. Prothrombin, or factor II, is one of the clotting factors made by the liver. Vita$\min \mathrm{K}$ is needed to make prothrombin and other clotting factors. Prothrombin time is an important test because it checks to see if five different blood clotting factors (factors I, II, V, VII and X) are present. An abnormal prothrombin time is often caused by liver disease or injury or by treatment with blood thinners. Hence prothrombin time is checked along with other liver tests, such as AST, ALT, ALP etc. to assess how liver is working [18]. In cadmium intoxicated rats the PT was drastically increased which may be attributed to decreased synthesis of prothrombin due to hepatocellular damage. Treatment with ALME resulted in the significant decrease in prothrombin time. The result of the test extract at $200 \mathrm{mg} / \mathrm{kg}$ was well comparable to that of silymarin $(100 \mathrm{mg} / \mathrm{kg})$, a reference drug.

Hematopoietic system is one of the most sensitive systems to assess the toxicity of environmental toxins and drugs in humans and animals. Cd exposure can cause normocytic normochromic anemia [16]. In accordance with other results, anemia has been reported in rats exposed to $\mathrm{Cd}$. Cadmium induced anemia could be as a result of the non essential toxic metal accumulation in kidney, spleen and liver might suppress the activity of these hematopoietic tissues [19]. Cd led to anemia as a result of accelerated erythrocyte destruction because of the altered erythrocyte membrane permeability, increased mechanical fragility, and/or failure of the 


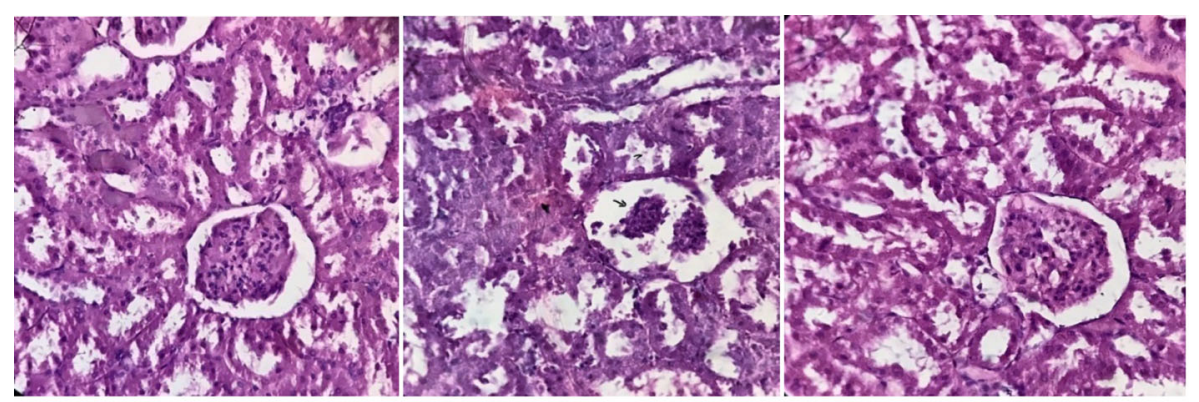

(A) Control group

(B) Toxic group

(C)Silymarin $100 \mathrm{mg} / \mathrm{kg}$

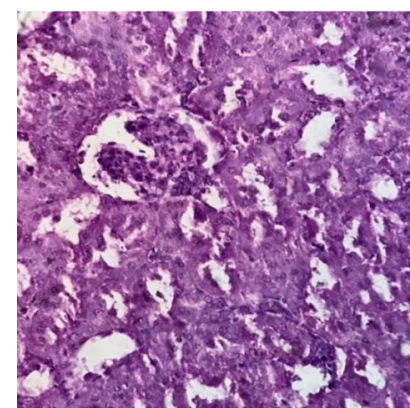

(D) ALME $100 \mathrm{mg} / \mathrm{kg}$

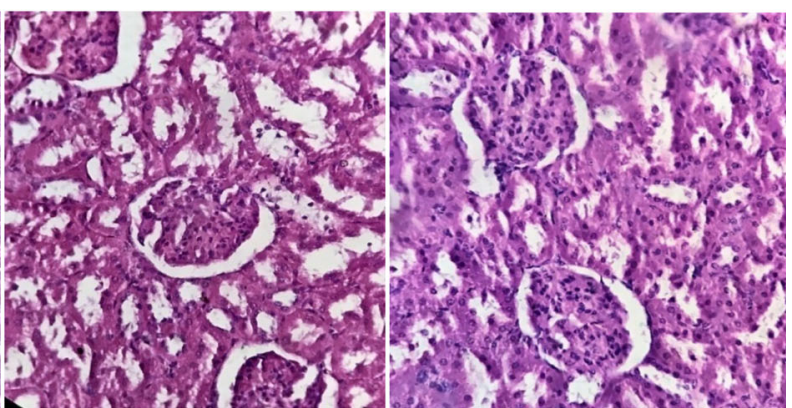

(E) ALME $200 \mathrm{mg} / \mathrm{kg}$
(F) ALME $400 \mathrm{mg} / \mathrm{kg}$

Fig. 2 Histopathological changes in renal tissue of rats. Done by Digital Motic Microscope Magnification 100X. a A control kidney with normal architecture. $\mathbf{b}$ Rats treated with cadmium alone, with congested shrunk and completely degenerated glomeruli, debris in the lumen of some renal tubules and degeneration of renal tubules. c And e Rats treated with Standard and ALME $200 \mathrm{mg} / \mathrm{kg}$, along with cadmium exhibited normal architecture. $\mathbf{d}$ Rats treated with ALME $100 \mathrm{mg} / \mathrm{kg}$ and cadmium showed mild degeneration of glomerulus. $\mathbf{f}$ Rats treated with ALME 400 $\mathrm{mg} / \mathrm{kg}$ and cadmium maintained normal renal corpuscle and renal tubule more or less like normal structure

intestinal uptake of iron because of mucosal lesions [20]. This anemia might be attributed to the deficient of erythropoietin hormone as a result of the impact of chronic cadmium intoxication on the erythropoietin producing cells in the kidney. ALME at 3 test doses have reported an increase in the total leukocyte count in ratintoxicated with $\mathrm{Cd}$, there was a leukocytosis in $\mathrm{Cd}$ treated rats. That increase was possibly occurred as a responsive mechanism to the degenerative changes caused by $\mathrm{Cd}$ in liver and kidney. Treatment with ALME has shown significant increase in RBC, Hb levels and decrease in WBC, when compared with the cadmium intoxicated rats. ALME could counteract the negative effects of $\mathrm{Cd}$ on the $\mathrm{RBC}, \mathrm{Hb}$ and leucogram.

The antioxidant defense system protects cells against reactive oxygen species (ROS) and lipid peroxidation. Cadmium promotes an early oxidative stress and afterwards contributes to the development of serious pathological conditions. Oxidative stress is one of the important mechanisms of toxic effect of cadmium. The mechanism of cadmium induced oxidative stress involves an imbalance between generation and removal of ROS in tissues and cellular components, causing damage to membranes, DNA and proteins [20].
Glutathione (GSH) is a multifunctional intracellular non enzymatic antioxidant, which is considered to be the major thiol-disulfide redox buffer of the cell. It serves many vital physiological functions, including protection of cells from ROS, detoxification of exogenous compounds, and amino acid transport with the help of the $\mathrm{SH}$ group present in them, which is essential for its antioxidant activity against some forms of ROS in the cells. A decreased level of GSH is observed in cadmium treated rats, are due to enhanced utilization of these antioxidants for scavenging free radicals [21]. Studies with cadmium revealed that the primary route for cadmium toxicity is the depletion of GSH and binding of $\mathrm{Cd}$ to $-\mathrm{SH}$ groups of proteins. The depletion of cellular sulfhydryl reserves seems to be an important indirect mechanism for oxidative stress induced by cadmium [16].

Suppression of free radical scavenging function and the enhancement of ROS, contributes to $\mathrm{Cd}$ induced oxidative stress, lipid peroxidation and its associated toxic effects. Lipid peroxidation is part to be an important mechanism of cell membrane injury and MDA is one of its end product, which is generated during the oxidative degeneration of lipids [21]. Catalase is a hemeprotein which catalyses the reduction of $\mathrm{H}_{2} \mathrm{O}_{2}$ to water 
and oxygen and thus protects the cell from oxidative damage by $\mathrm{H}_{2} \mathrm{O}_{2}$ and $\mathrm{OH}$ [22]. Decreased activity of CAT may also be due to the direct binding of the metal to the active site of the enzymes or due to their increased usage in scavenging free radicals induced by the metal thus causing irreversible inhibition in their activities [11]. Cd induced liver damage is associated with increased lipid peroxidation [23]. Oral administration of ALME increased the activities of GSH, CAT and decreased the levels of MDA in tissue homogenates of cadmium treated rats, may be due to increasing the activity of the antioxidant defense system and scavenging the ROS as well as inhibiting lipid peroxidation, which might be due to the ability of flavonoids and polyphenols present in ALME.

\section{Conclusion}

ALME at a dose of $200 \mathrm{mg} / \mathrm{kg}$ b.wt. exhibited more significant protective effect against cadmium induced hepatotoxicity and nephrotoxicity; it was well comparable to that of a known phytogenic hepatoprotective drug, Silymarin $(100 \mathrm{mg} / \mathrm{kg})$. The hepatorenal protective effect of the extract, ALME was supported by its effect in shortening the prothrombin time, changes in hematological properties, its antioxidant property and histopathological studies. The studies substantiated the traditional claim of Antigonon leptopus for the treatment of liver disorders. Thus to conclude, the beneficial effects of ALME on restoring cadmium induced impairment of hepatic and renal function are likely to be mediated by its antioxidant activity.

\section{Abbreviations \\ Cd: Cadmium; ALME: Antigonon leptopus methanolic extract; GSH: Glutathione; AST: Aspartate aminotransferase; ALP: Alkaline phosphatase; ALT: Alanine aminotransferase; TB: Total bilirubin; DB: Direct bilirubin; TP: Total protein; ALB: Albumin; MDA: Malondialdehyde; CAT: Catalase; TCA: Trichloro acetic acid; TBA: Thio barbituric acid; $\mathrm{Hb}$ : Hemoglobin}

\section{Acknowledgements}

We acknowledge Kakatiya University, Warangal (Telangana), India, for providing all the facilities to perform experimental work.

\section{Authors' contributions}

MP performed all the animal studies, the analysis and also drafted the manuscript and design the figures. SRV design the study, interpreted the results and worked on the manuscript. All authors discussed the results and commented on the manuscript.

\section{Funding}

Not applicable.

\section{Availability of data and materials}

All the data was analyzed by using the software, Graph pad prism 6.0 version which is available online.

\section{Ethics approval}

The animal studies were performed with a prior permission from our institutional animal ethical committee with registered number.

\section{Competing interests}

The authors declare that they have no competing interests.

Received: 14 October 2019 Accepted: 20 May 2020

Published online: 26 May 2020

\section{References}

1. Mohamed A. Dkhil, Saleh Al-Quraishy, Marwa MS Diab, Mohamed S Othman, Ahmed M Aref, Ahmed E Abdel Moniem. Food Chem Toxicol. 2004;74:98-106.

2. El-Habit O, Abdel Moniem AE. Testing the genotoxicity, cytotoxicity, and oxidative stress of cadmium and nickel and their additive effect in male mice. Biol Trace Element Res. 2014;159:364-72.

3. Bellinger D, Bolger M, Egan K, Feeley M, Schlatter J, Tohyama C. Contaminants: cadmium. World Health Organisation Food Additives Series No 52; 2004.

4. Jarup L, Hellstrom L, Alfven T, CarlssonMd GA, Persson B. Low level exposure to cadmium and early kidney damage. Occup Environ Med. 2000;57:668-72.

5. Agency for Toxic substances and Disease Registry ATSDR. Toxicological profile for cadmium. Atlanta: Agency for Toxic substances and Disease Registry; 1999.

6. Swaroopa Rani V, Sujatha S, Krishna mohan G, Ravi kumar B. Antidiabetic effect of Antigonon leptopus Hook \& Arn leaf on Streptozotocin-induced diabetic rats. Pharmacology. 2010;2:922-31.

7. Ohkawa H, Ohishi N, Yagi K. Assay for lipid peroxides in animal tissues by thiobarbuturic acid reaction. Anal Chem. 1979;95:351-8.

8. Ellman GL. Tissue sulfhydral groups. Arch Biochem Biophys. 1959:82:70-7.

9. Kawamura N, Taniguchi N, Gutteridge JMC. Experimental protocols for reactive oxygen and nitrogen species. New York: Oxford University Press Inc; 2000 .

10. Williamson EM, Okpako DT, Evans FJ. Pharmacological methods in phytotherapy: selection, preparation and pharmacological evaluation of plant material (1st edition). Chichester, England: Wiley; 1996. p. 131-54.

11. Renugadevi J, Prabhu SM. Cadmium induced hepatotoxicity in rats and the protective effect of naringenin. Exp Toxicol Pathol. 2010;62:171-18.

12. Moss DW, Butterworth PJ. Enzymology and medicine. Pitman Med London. 1974;6:3-11.

13. Liss G, Greenberg RA, Tamburro CH. Use of serum bile acids in the identification of vinyl chloride hepatotoxicity. Am J of Med. 1985;78:68-73.

14. Milton prabhu S, Selvrajan N, Hemalatha S, Ramesh Kumar T. Hepatoprotectiveeffect of Andrographis paniculata on cadmium induced toxicity in male wistar rats. Int J Toxicol. 2008;15:21-5.

15. Satyanarayana U, Chakrapani U. Essentials of biochemistry ( $2^{\text {nd }}$ edition). New Delhi: Elsevier Health Sciences; 2008.

16. El B, Risha EF, et al. Protective effects of selenium against cadmium induced hematological disturbances, immunosuppressive, oxidative stress and hepatorenal damage in rats. J Trace Elem Med Biol. 2004;29: 104-10.

17. Godt J, Scheidig F, Grosse-siestrup C, Esche V, Brandenburg P, Reich A, et al. The toxicity of cadmium and resulting hazards for human health. J Occup Med Toxicol. 2006:333:22-9.

18. Parks R. WebMD medical reference from Healthwise September 15; 2008.

19. Ashour TH. Preventative effects of caffeic acid phenyl ester on cadmium intoxication induced hematological and blood coagulation disturbances and hepatorenal damage in rats. ISRN Hematol. 2014;3:1-7.

20. Akinyemi AJ, OnyebuekeN FAO, Onikanni SA. Curcumin inhibits adenosine deaminase and arginase activities in cadmium induced renal toxicity in rat kidney. J Food Drug Analysis. 2016;355:1-9.

21. Thampi HBS, Manoj G, Leelamma S, Menon VP. Dietary fiber and lipid peroxidation: effect of dietary fiber on levels of lipids and lipid peroxides in high fat diet. India J of Experimental Biol. 1991;29:563-7.

22. Chance B, Greenstein DS, Roughton RJW. The mechanism of catalase action 1-steady state analysis. Arch Biochem Biophys. 1952;37:301-39.

23. Shimada T, Takamure Y, Shimada A, Yasutake A. Strain differences of cadmium induced hepatotoxicity in wistar-imamichi and fischer 344 rats: involvement of cadmium accumulation. Toxicology. 2014;203:189-97.

\section{Publisher's Note}

Springer Nature remains neutral with regard to jurisdictional claims in published maps and institutional affiliations. 